\title{
Nadir Görülen Primer Saplanma Baş Ağrısı: Bir Olgu Sunumu
}

\author{
The Rare Primary Stabbing Headache: A Case Report
}

\author{
Arzu Çoban, Mustafa Ertaş* \\ Balıkesir Üniversitesi Tip Fakültesi, Nöroloji Anabilim Dalı, Balıkesir, Türkiye \\ *Anadolu Sağlık Merkezi, Nöroloji Bölümü, Kocaeli, Türkiye
}

Özet

Primer saplanma baş ağrısı, çok kısa süreli ataklarla karakterize, ağırlıklı olarak trigeminal sinirin birinci dalına uyan bölgede görülen bir primer baş ağrısı sendromudur. Ağrının iyi cevaplı olmasından dolayı indometazin tedavide seçilecek ilk ilaçtır. Bu yazıda ağrının özelliği ve indometazine iyi cevaplı olması ile tipik olarak primer saplanma baş ağrısı kriterlerini taşıyan 25 yaşında bir kadın hasta sunuldu. Primer saplanma baş ağrıları sanıldığı kadar nadir olmasa da atak sıklığının az ve süresinin kısa olmasında dolayı nadir doktora başvuru sebebidir. Klinik pratikte bilinmesi tedaviye iyi cevaplı olması açısından çok önemlidir. Doğru tanı ile tedaviye alınan cevap tatmin edicidir. (Türk Nöroloji Dergisi 2012; 18:30-2)

Anahtar Kelimeler: Primer saplanma baş ă̆rısı, indometazin, tedavi

\section{Summary}

The primary stabbing headache is a syndrome characterized by ultrashort attacks confined to the head, exclusively or predominantly felt in the distribution of the first division of trigeminal nerve. The indomethacin is the drug of first choice for treatment due to headache is good response. In this article, a 25 -yearold woman was presented that fulfilling the criteria of typical primary stabbing headache due to clinical features and indomethacin good responsive headache. The primary stabbing headache is not uncommon. However, most people have attacks of low frequency and short-term, so they seldom visit the doctor. Because of good response to treatment in clinical practice is very important to know the primary stabbing headache. The response to treatment was satisfactory with the correct diagnosis. (Turkish Journal of Neurology 2012; 18:30-2)

Key Words: Primary stabbing headache, indomethacin, treatment

\section{Giriş}

Primer saplanma baş ağrısı, 2004 yılında Uluslararası Baş ağrısı Komitesi (UBK) tarafindan yayınlanan yeni sınıflamada nadir görülen diğer primer baş ağrıları sınıfında yer alır (1). Klinik olarak, genelde trigeminal alanda birkaç saniye sürebilen ve gün içinde birden fazla tekrarlayabilen biçak saplanır gibi batıcı ağrılarla karakterizedir (2). İndometazin tedavisi ile saplanma ağrılarında çok iyi cevap alındığı için tedavide ilk seçenek olarak kullanılır $(3,4)$. Hatta indometazine verilen cevabın tanısal değeri de olabilir.
$\mathrm{Bu}$ yazıda, baş ağrısı özellikleriyle nadir görülen primer saplanma baş ağrısını düşündüren ve indometazine çok iyi cevap veren bir olgu tartışılacaktır.

\section{Olgu Sunumu}

Yirmi beş yaşında kadın hasta, yaklaşık bir aydır devam eden, gün aşı1ı ya da 2-3 günde bir olabilen, ortalama birkaç saniye ya da en fazla 1 dakika devam eden, sol temporal ve periorbital bölgede olan, çok şiddetli, bıçak saplanır tarzda delici ve oyucu karakterde bir baş ağrısı yakınmasıyla başvurdu. Ağrının şiddetli

Yazışma Adresi/Address for Correspondence: Dr. Arzu Çoban, Balıkesir Üniversitesi Tıp Fakültesi, Nöroloji Anabilim Dalı, Balıkesir, Türkiye Gsm: +90 5325757776 E-posta: arzucoban2002@yahoo.com

Geliş Tarihi/Received: 01.09.2011 Kabul Tarihi/Accepted: 03.11.2011 
döneminden sonra aynı bölgede birkaç saat boyunca hafif bir ağrının devam ettiği öğrenildi. Zaman zaman sağ temporal bölgede de olan ağriya otonomik bulgular ile bulantı ve kusma eşlik etmiyordu. Her atakta burnunda iki yanlı basınç hissi tarifliyordu. Özgeçmiş ve soygeçmişinde bir özellik yoktu. Nörolojik muayenede bir özellik saptanmadı.

Geniş biyokimya, hemogram, sedimentasyon, CRP değerleri normaldi. Etyolojik amaçlı yapılan kranyal MR incelemesinde özellik saptanmad1.

Bu klinik tablo ile ön planda primer baş ağrılarından saplanma baş ağrısı ile ağrı süresinin kısa olmasından dolayı paroksismal hemikrani ve daha geri planda SUNCT (Short lasting unilateral neuralgiform headache with conjunctival injection and tearing) sendromu düşünüldü. Ancak otonom bulguların eşlik etmemesi ile bu tanılardan uzaklaşıldı. Tedavide verilen indometazin fitil 1x100 mg ile ağrılar yaklaşık 1 ayda yarı yarıya azaldı. İlaç 2x100 mg yapıldıktan 15 gün sonra da ağrılar tama yakın geriledi.

\section{Tartışma}

Primer saplanma baş ağrısı, kısa süreli, şiddetli ve gün içinde çok sayıda tekrarlayabilen genellikle trigeminal sinirin birinci dalına uyan bölgede görülen bir baş ağrısı sendromudur $(5,6)$. Kadınlarda erkeklere göre daha sık görülür (7). Bazı durumlarda şiddetli saplanmanın olduğu bölgede daha künt ve hafif bir ağr1 dakikalar veya saatler içinde devam edebilir (8). Ataklarda ağr1 sıklıkla bir bölgeden diğerine doğru yayılarak değişik lokalizasyonlar gösterebilir $(6,9,10)$. Bazen ağrı trigeminal alanın dışındaki bölgelerde de (aurikular, posterior parietal, oksipital) görülebilir (6). Genelde migren tipi baş ağrısı olanların \%40'ında ve küme tipi baş ağrısı olanların da \%30'unda bu tip ağrılar görülebilir $(2,8)$. Bu tür ağrılar, yaygın olarak rastlanan migren ve gerilim tipi baş ağrılarına göre daha nadir görülmelerine rağmen oldukça rahatsız edicidir (5). Tedavide standart baş ağrısı tedavilerinden farklı bir yol izlendiği için tanı koyulması da oldukça önemlidir.

Trigeminal nevralji, küme baş ağrıları, paroksismal hemikraniler ve SUNCT gibi diğer primer baş ağrıları da gerek ağrıların kısa süreli olması gerekse aynı bölgede görülmeleriyle primer saplanma baş ağrılarının ayırıcı tanısında yer alan baş ağrısı sendromlarıdır. Ancak bu sendromların bazılarında baş ağrısına otonomik bulgular (küme baş ağrıları, paroksismal hemikraniler ve SUNCT sendromu) eşlik ederken; bir kısmında da ağrının bazı aktivitelerle tetiklenmesi (trigeminal nevralji) söz konusudur.

Primer saplanma baş ağrısı indometazine cevaplı bir baş ağrısı sendromudur (3,11). Mekanizması tam bilinmese de indometazin'in beyin kan akımını ve BOS basıncını azaltarak etkili olduğu düşünülmektedir (12). Yapılan bazı çalışmalarda siklooksijenaz-2 inhibitörleri $(6,13,14)$, gabapentin (15), nifedipin (16), parasetamol (17) ve melatonin (18) gibi ajanların da tedavi de etkili oldukları gösterilmiştir.
Bizim olgumuzda da gerek ağrının çok kısa süreli olması gerekse dağılım yeri göz önüne alındığında ayırıcı tanıda paroksismal hemikrani ve SUNCT sendromu düşünülmüş; ancak ağrının indometazin tedavisine cevap vermesi, otonomik bulguların eşlik etmemesi, gün içinde çok sayıda tekrarlamamasıyla bu tanılardan uzaklaşılmış ve olgunun tipik özellikleriyle primer saplanma baş ağrısı sınıfında yer almasının uygun olacağı kanaatine varılmıştır.

Literatürde primer saplanma baş ağrısı ile ilgili çeşitli çalışmalar bildirilmiştir $(2,6,17,19,20)$. Popülasyon çalışmalarında, primer saplanma baş ağrısının sanılanın aksine yaygın olduğu gösterilmiştir (4). Yeni yayınlanan 36 hastalık bir başka çalışmada da primer saplanma baş ağrısının aslında nadir olmadığ 1 ancak baş ağrısı kliniğine ana başvuru sebebi olmadığ 1 için nadir gibi görüldüğ ü bildirilmiştir (2). Otuz bir hastalık başka bir çalışmada primer saplanma baş ağrısının sıklığ $\% 12,6$ olarak bildirilmiş (19); 80 hastalık başka bir çalışmada ise primer baş ağrısının hem yaygın hem de kolay tedavi edilebilir bir hastalık olduğu bildirilmiştir (6).

Sonuç olarak primer saplanma baş ağrıları sanıldı ̆̆ı kadar nadir olmasa da diğer sık görülen primer baş ağrıları kadar kliniğe başvuru sebebi olmadığı için tanınması daha zordur. Tanısı iyi bir anamnez ve görüntüleme yöntemleri ile altta yatabilecek olan yapısal lezyonların dışlanması ile koyulabilir. Şiddetli ağrıya yol açan bu hastalığın tanınması tedaviye iyi cevaplı olmasından dolayı zaman kaybını önlemek için çok önemlidir.

\section{Kisaltmalar}

UBK: Uluslararası baş ağrısı komitesi;

CRP: C-reaktif protein; MR: Manyetik rezonans;

SUNCT: Short lasting unilateral neuralgiform headache with conjunctival injection and tearing;

BOS: Beyin omurilik sıvısı.

\section{Kaynaklar}

1. Headache classification Subcommittee of the International Headache Society. The International Classification of Headache Disorders. Cephalalgia 2004;24:276-84.

2. Guerrero AL, Herrero S, Peñas ML, Cortijo E, Rojo E, Mulero P, et al. Incidence and influence on referral of primary stabbing headache in an outpatient headache clinic. J Headache Pain 2011;12:311-3.

3. Dodick DW. Indomethacin-responsive headaches syndromes. Curr Pain Headache Rep 2004;8:19-26.

4. Pareja JA, Sjaastad O. Primary stabbing headache. Handb Clin Neurol 2010;97:453-7.

5. Newman LC. Effective management of ice pick pains, SUNCT, and episodic and chronic paroxysmal hemicrania. Curr Pain Headache Rep 2001;5:292-9.

6. Fuh JL, Kuo KH, Wang SJ. Primary stabbing headache in a headache clinic. Cephalalgia 2007;27:1005-9.

7. Sjaastad O, Pettersen H, Bakketeing LS. Extracephalic jabs/idiopathic stabs. Vågå study of headache epidemiology. Cephalalgia 2003;23:50-4.

8. Ferrante E, Rossi P, Tassorelli C, Lisotto C, Nappi G. Focus on therapy of primary stabbing headache. J Headache Pain 2010;11:157-60. 
9. Pareja JA, Ruiz J, De Isla C, Al-Sabbah H, Espejo J. Idiopathic stabbing headache (jabs and jolts syndrome). Cephalalgia 1996;16:93-6.

10. Sjaastad O, Pettersen H, Bakketeig LS. The Vagå study of headache epidemiology II. Jabs: clinical manifestations. Acta Neurol Scand 2002;105:25-31.

11. Rozen TD. Short-lasting headache syndromes and treatment options. Curr Pain Headache Rep 2004;8:268-73.

12. Dodick DW. Indomethacin-responsive headaches syndromes: a hypothesis on the mechanism underlying the efficacy of indomethacin in these disorders. Neurology 1999;52:A210.

13. Piovesan EJ, Zukerman E, Kowacs PA, Werneck LC. COX-2 inhibitor for the treatment of idiopathic stabbing headache secondary to cerebrovascular diseases. Cephalalgia 2002;22:197-200.

14. O' Connor MB, Murphy E, Phelan MJ, Regan MJ. Primary stabbing headache can be responsive to etoricoxib, a selective COX-2 inhibitor. Eur J Neurol 2008;15:e1.
15. Franca MC Jr, Costa AL, Maciel JA Jr. Gabapentin responsive idiopathic stabbing headache. Cephalalgia 2004;24:993-6.

16. Jacome DE. Exploding head syndrome and idiopathic stabbing headache relieved by nifedipine. Cephalalgia 2001;21:617-8.

17. Fusco C, Pisani F, Faienza C. Idiopathic stabbing headache:clinical characteristic of children and adolescents. Brain Dev 2003;25:237-40.

18. Rozen TD. Melatonin as a treatment for idiopathic stabbing headache. Neurology 2003;61:865-6.

19. Tuğba T, Serap U, Esra O, Ozlem C, Ufuk E, Levent E I. Features of stabbing, cough, exertional and sexual headaches in a Turkish population of headache patients. J Clin Neurosci 2008;15:774-7.

20. Shin JH, Song HK, Lee JH, Kim WK, Chu MK. Paroxysmal stabbing headache in the multiple dermatomes of the head and neck: a variant of primary stabbing headache or occipital neuralgia? Cephalalgia 2007;27:1101-8. 